〈费芸化学奖励賞〉

\title{
生体内脂質の過酸化により生じる極微弱化学発光の解析と応用に関する研究
}

生体内に過酸化脂質が生成すると, 動物組織を構 成する諸種の細胞の機能は低下し，ついで細胞壊死 をもたらす。こうした現象は，臨床的な各種疾病と も密接に関連すると思われる、しかし，従来の脂質 過酸化測定法では生体試料中の過酸化脂質, とくに 反応一次産物である脂質ヒドロパルオキシド，の特 異的な定量注困難である。また, 多種多様な反応過 程をもつ生体脂質過酸化も，酸化的なラジカ儿連鎖 反応を含むという共通点があるといえるが，この過 程で生じるラジカルは短寿命であり，生体組織には ラジカルを除去するシステムも発達しているので, その検出は電子スピン共鳴（ESR）法を用いても容 易でない. ある種の酸化反応は弱い化学発光（ケミ ルミネッセンス，CL）を伴うことが知られている。 そこて，生体試料でも組織脂筫過酸化のときに脂質 ラジカルや活性酸素の生成に基づく発光現象がある と考えることができる。このような過酸化ラジカル の生成を反映する測定法が開発され，生体試料に応 用できれば，従来捕捉できなかった生体情報が得ら れるはずである。

本研究は，生体組織中の脂質が過酸化反応を受け たときに生じる極微弱な化学発光を検出してその性 質を解明し，極微弱光検出法を生体内脂質の過酸化 に伴う遊離基生成度の判定に応用しようとしたもの であり，組織脂質の劣化，老化過程や栄盖成分の組 織内ラジカ儿産生への影響およびヒト各種疾患での 組織発光の詳細を究明した, さらに，生体組織の㥛 微弱発光発現のメカ二ズムを応用して, 超微量の過 酸化脂質（ヒドロペルオキシド）の定量法を確立し， 生体組織中のヒドロペルオキシドを脂貿クラスレベ ルで特異的に検出定量することに成功した。また， 本法を用いて, 発癌初期の標的蔵器内でのリン脂質 ヒドロペルオキシドの生成著增を証明した。その概 要を以下に示す.

\section{1. 極微弱光検出装置の開発}

生体組織からの自発的な䄈微弱光を検出する日的 で, 来北大学電気通信研究所稲場教授グループとの 共同研究により, 光電子増倍管用いた単一光電子 計数方式による極微弱光検出計数装置（ケミルミネ ッセンスアナライザー, 図 1) を開発完成させた。

\section{東北大学農学部 宮 沢 陽 夫}

剆定試料は，血液や各種臟器およびそのホモジネ一 トなどであり，常温空気中での試料からの極微霌光 観测が可能になった，本装置を用いて，血液や肝藏 をはじめ種々の臟器組織から毎秒1〜100カウント の光子放出があることを確認し，その発光強度が $10^{-15} \sim 10^{-18} \mathrm{~W}$ であることを明らかにした。

\section{2. 生体微弱発光発現機構の解明}

組織脂貿過酸化を進行させた酸化油投与動物など で観測された生体極微弱発光は，発光発現に酸素を 必要とし, 遊離基反応の阻害剂である $\alpha$-トコフェ口 ールやブチルヒドロキシトルエン (BHT) で効果的 に阻害されることを見出した。また，肝ホモジネー トに脂質上ドロペルオキシドを加えた in vitro 系で も同じ特性の強い発光を諗め，へモグロビン，ミオ グロビン，チトクロムcなどのへム化合物と脂質ヒ ドロペルオキシドの反応でも類似の化学発光を観测 した．生体組織発光は，フェニルーN-tert-ブチルニ トロン (PBN) をはじめとするスピントラップ剂で

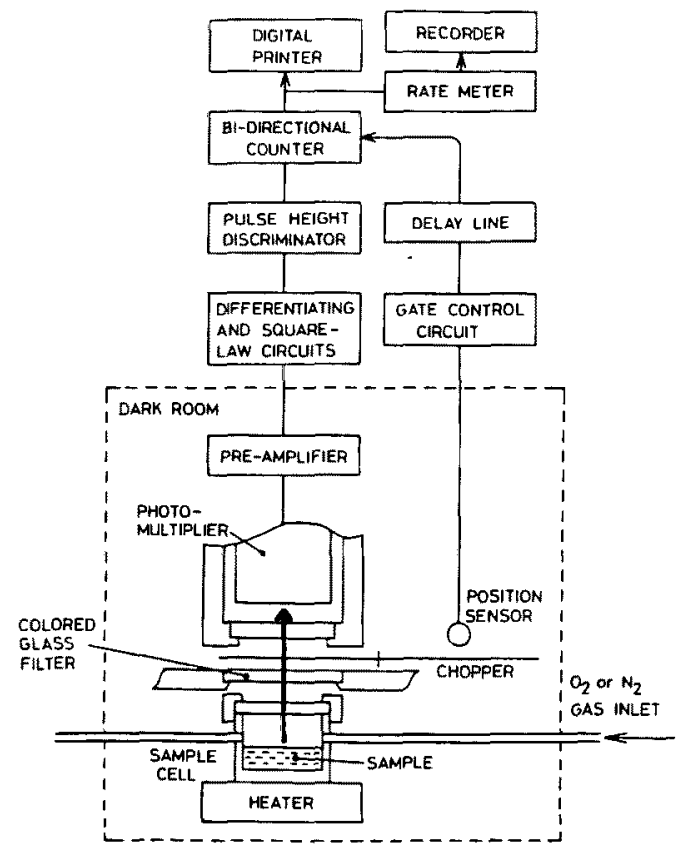

図 1 極微弱光検出のための単一光電子評数装置の ブロック図 


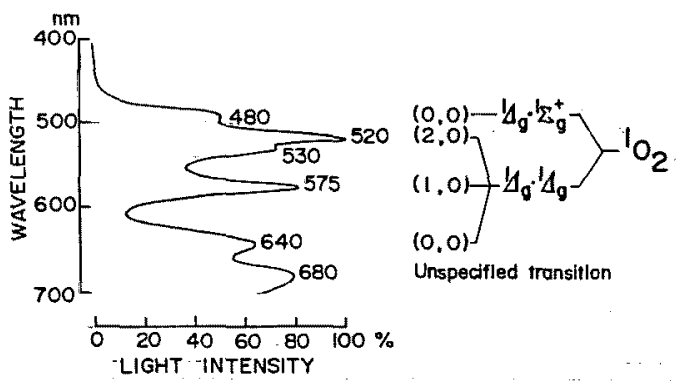

図 2 脂質ヒドロペルオキシドが存在するラット肝 臟の極微弱発光スベクトル

強く阻害されこのとき捕捉されたラジカルの ESR スペクトルの解析から, 脂質ペルオキシラジカル (ROO・) とアルコキシラジカル (RO・) などの酸素 ラジカルが生成し，これが発光に関与することを明 らかしした．生体極微弱発光は，いずれも一重項酸 素 $\left({ }^{1} \mathrm{O}_{2}\right)$ の消去剤で強く阻害されたが, この場合, 化学的手法による ${ }^{\prime} \mathrm{O}_{2}$ 検出は困難なので, 極微弱光 用に高感度化したフィルタースペクトル分析装置で 発光スペクトルの解析による発光種の同定をした. すなわら，化学的 ${ }^{\mathrm{I}} \mathrm{O}_{2}$ 生成系でのスペクトル分布の 比較から, 生体組織からの自発的な極微弱発光が主 として ${ }^{1} \mathrm{O}_{2}$ に由来し， $2\left[{ }^{1} \Delta_{9}\right] \rightarrow 2\left[{ }^{3} \Sigma_{9}^{-}\right]$に対応した ${ }^{1} \mathrm{O}_{2}$ の ${ }^{3} \mathrm{O}_{2}$ (分子状基底酸素) への遷移エネルギーに よる化学発光であることを証明した(図 2)。このと き, ${ }^{1} \mathrm{O}_{2}$ は脂質ペルオキシラジカルの二分子分解反 応（ラッセル反応）で生じると考えられる。

\section{3. 極微弱光検出法の生体脂質過酸化度判定への} 応用

生体脂質過酸化モデル（酸化油投与, ビタミン $\mathrm{E}$ 欠之, 四塩化炭素投与, 放射線照射など）動物の各 缄器の発光量が著増することを見出し，極微弱光検 出が生体脂質過酸化度とくに遊離基生成度の判定に

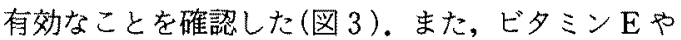
$\mathrm{B}_{2}$ など栄湌成分による組織内ラジカル消去能を各

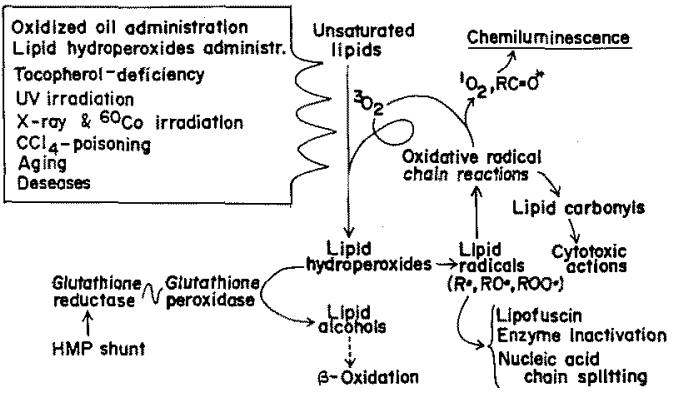

図 3 生体内脂質過酸化と極微弱化学発光の関係
種動物を用いた in vivo 実験で明らかにし，抗酸化 効果の臟器別差異や相乗効果についても新知見を得 た。一方, ラットの加龄に伴う脳などの極微弱発光 強度の変化を調べ，加齢に伴う葴器発光増大を見出 し，老化遊離基説への新論拠を示した。

\section{4. 超微量過酸化脂質定量法の確立}

生体極微弱発光の発現機構を応用し，従来生体試 料での分析が困難であった過酸化反応一次産物であ るヒドロペルオキシドを, 高感度（数ピコモル）か つ特異的に脂質クラスのレベルに分離した状態で定 量可能な, 化学発光一高速液体クロマトグラフィー (CL-HPLC) 法を開発した（図 4)。本法を用いて, ヒト血漿中のホスファチジルコリンヒドロペルオキ シド $(\mathrm{PCOOH})$ の存在をはじめて証明した（図 5 ).

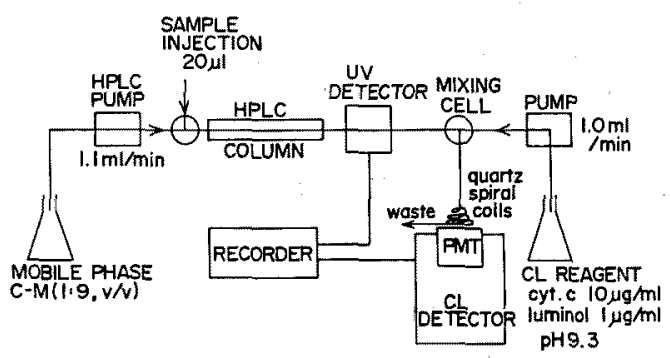

図 4 化学発光-高速液体クロマトグラフィー (CL-HPLC) のブロック図

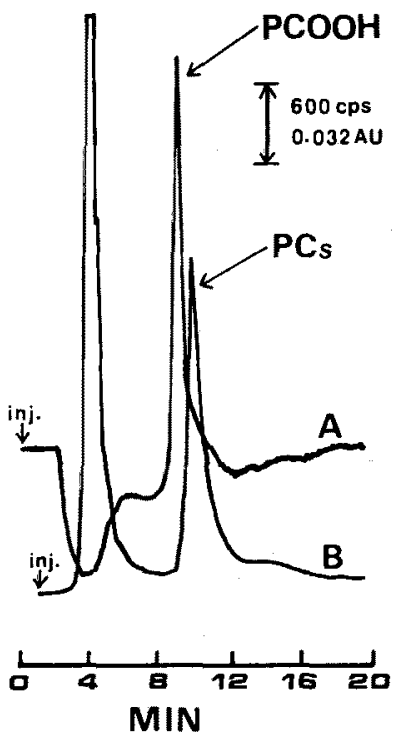

图 5 健常人血漿中のホスファチジルコリンヒドロペル オキシド (PCOOH)の CL-HPLC 分析によるクロ マトグラム

$\mathrm{A} ：$ 化学発北検出によるクロマトグラム

B：共役ジエン吸収檢出によるクロマトグラム 
また，各種の脂貣過酸化動物モデルにおいて，機能 性リン脂質であるホスファチジルコリンが組織内で 確実にヒドロペルオキシド化されていることを経時 的，定量的に明らかにした。

5. 発癁過程でのヒドロペルオキシド生成の証明 CL-HPLC 法を用いて，発癌初期過程の動物の標 的蔵器内において，ホスファチジルコリンヒドロペ ルオキシドが顕著に生成（コリン欠乏エチオニン添 加食依存マウス肝癌モデルにおいて正常葴器の約 5 倍することをはじめて定量的に証明し，発癌と脂 質過酸化の関係に新たな仮説を示した。
本研究は, 東北大学農学部食糧化学科食品学教室 で行われたものであり,研究の機会を与えて下さり， 終始基切なご指導を賜りました東北大学名誉教授金 田尚志先生に厚く御礼申し上げます。また，貴重な ご助言をいただいた東北大学電気通信研究所稲場文 男教授, 東北電子産業(株)佐伯昭雄博士, 尚絅女学 院短期大学薄木理一郎教授に感謝いたします。さら に, 東北太学農学部食品学教室の藤本健四郎教授は じめ共同研究をしていただいた研究室の皆様方に御 礼申し上げます。おわりに，脂質研究への道をご教 示いただいた帯広畜産大学名誉教授藤野安彦先生に 深く感謝いたします。 